\title{
FUZZY MODELING OF THE EFFECTS OF DIFFERENT IRRIGATION DEPTHS ON THE RADISH CROP. PART I: PRODUCTIVITY ANALYSIS
}

\author{
Ana C. M. R. Boso', Camila P. Cremasco², Fernando F. Putti², Luís R. A. Gabriel Filho* \\ ${ }^{2 *}$ Corresponding author. São Paulo State University (UNESP), School of Sciences and Engineering/ Tupã - SP, Brasil. \\ E-mail: gabriel.filho@unesp.br | ORCID ID: http://orcid.org/0000-0002-7269-2806
}

\section{KEYWORDS}

water optimization, fuzzy logic, tuberous, Gaussian.

\begin{abstract}
The productivity of a crop is related to the water demand inserted in its development. The measurement of water and its optimization directly influences the final costs of crop production for agricultural producers. In this sense, the objective of this study is evaluating the fuzzy modeling in estimating the productivity of the radish crop (fresh phytomass of the tuberous root) affected by different irrigation depths $(25 \%, 50 \%, 75 \%$, $100 \%$, and 125\%), based on evapotranspiration of the crop (ETc). To measure the results, two fuzzy systems (with triangular and Gaussian membership functions respectively) and a polynomial regression model were developed to perform model validation comparisons. The fuzzy modeling showed a better fit of the data compared to the polynomial regression model, with reduced errors (RMSE with values 6.3 and 6.9 in the fuzzy models versus 8.8 in the regression model) and higher correlation coefficient ( 0.54 and 0.5 fuzzy versus 0.1 regression). The triangular fuzzy model estimated the best crop yield ( $31.9 \mathrm{~g}$ of fresh phytomass) when using a 100\% ETc depth. Also, the curve generated by the fuzzy model accurately represents all the productivity averages in each depth, in addition to this model presenting the smallest errors (compared to the triangular model and the regression model) and the highest $\mathrm{R}^{2}$. However, the Gaussian fuzzy model proved to be more efficient in representing the agronomic reality, as it does not have peaks and valleys, and it is a smooth model in both growth and degrowth.
\end{abstract}

\section{INTRODUÇÃO}

The radish (Raphanus Sativus L.) is a vegetable that belongs to the Brassicaceae family, such as cauliflower, arugula, cabbage, among others. There is a controversy about the origin of the radish, as there are records of its cultivation in China, Europe, West Asia, and the Mediterranean region (Silva et al., 2015a).

Its characteristics stand out in edible tuberous roots, oval, round, and elongated, with reddish, white or red, white, black, and purple colors (Matos et al., 2015). Its diameter varies between 2 to $5 \mathrm{~cm}$, with white pulp, satisfying the consumer's taste (Rodrigues et al., 2013).

The radish is a vegetable that does not have much importance about the planted area but is grown on a large scale on small properties in several regions. Its cycle is considered short, and the harvest can be carried out between
25 and 35 days after sowing (Dutra et al., 2014, Santos et al., 2014).

As it is crop-sensitive to transplantation, sowing is carried out directly in the final area, with nutrient needs in large quantities in a short period, mainly nitrogen and potassium (Dutra et al., 2014; Coutinho Neto et al., 2010).

The productivity of the crop is related to the amount of water available for its development. According to Bregonci et al. (2008), water stress directly and negatively affects the diameter of the tuberous root and the roots of the radish. In his study, the author verified a $33 \%$ decrease in the diameter of the radish tuberous root on the control and effects on the length of the roots of the second cycle, when submitted to water deficit. According to Silva et al. (2015b), the radish's productivity and quality are reduced according to the water stress of the soil, obtaining cracks and spongy aspects in its roots.

${ }^{1}$ São Paulo State University (UNESP), School of Agriculture/ Botucatu - SP, Brasil.

${ }^{2}$ São Paulo State University (UNESP), School of Sciences and Engineering/ Tupã - SP, Brasil. 
Observing the effects generated in the productivity of the crop, for the inadequate handling of the same, and in the influence of the amount of the depths used in the irrigation, the agricultural experimentation has become an important factor in the investigation of new technologies, as in the reuse of liquid and solid residues, potentization of resources and other influencing factors (Putti et al., 2017a).

The use of more advanced techniques allows the search for new structures to support the data obtained in the field, such as the expansion of studies related to the evolution of nutrients that are extracted from the soil and cover the entire body structure of the plant, the reduction of water used for crop irrigation and crop productivity.

Mathematical modeling has become an area of great relevance in implementing the data obtained experimentally. However, there are situations of complexities that require more specific and advanced modeling to solidify the results. The fuzzy logic allows for a more comprehensive analysis of the data obtained (Gabriel Filho et al., 2011; Putti et al., 2017b).

The concepts of fuzzy logic are applied in principles that traditional logic does not allow explanations. Together, the fuzzy theory makes it possible to perform reasoning close to that of human beings in environments with uncertainties (Senna et al., 2015, Raj \& Mohan, 2016, Sousa et al, 2006.

The use of fuzzy theory is used in several areas of knowledge, such as in the poultry area, in modeling the impacts generated on the surface of the broiler by different temperatures (Bahuti et al., 2018), in the sphere of medicine in analyzing the need to administer vasopressors in ICU patients (Salgado et al., 2016), in the agricultural sector in obtaining reference evapotranspiration, replacing the conventional methodology (Kisi, 2013), among other compositions involving mathematical and computational methods that this logic is capable of to develop.

In this way, the present work aims to evaluate the fuzzy modeling to estimate the productivity behavior of the radish crop affected by different irrigation depths.

\section{MATERIAL AND METHODS}

\section{Experiment location}

Based on the experiment described in Cremasco et al. (2015), the productivity analysis of the radish crop was carried out using fuzzy modeling. The experiment took place between September and November in 2013, on the premises of the Department of Rural Engineering at UNESP
- Faculty of Agronomic Sciences in Botucatu-SP, located at $22^{\circ} 51^{\prime} \mathrm{S}$ and $48^{\circ} 26^{\prime} \mathrm{W}, 786 \mathrm{~m}$ above sea level.

The experiment was carried out in a completely randomized design, with 5 treatments (irrigation depths) and 5 repetitions, where the repetition was the plant. The crop used for the experiment was from the company Sakata with the definition: Maçarias - Radish $\mathrm{n}^{\mathrm{o}}$ 19. Its sowing occurred directly in the soil, with the beginning of thinning at 14 days after sowing (DAS). However, the evaluations for the development and productivity of the crop of the present work occurred on the 35th day after sowing (DAS).

Irrigation was carried out daily at 8 am using two independent systems, with a main and secondary drip line. The drippers used were the tape type, Amandani, manufactured by Petroísa Irrigations LTDA, where they were separated by $0.30 \mathrm{~m}$, obtaining a pressure of 10 m.c.a. and an average discharge of $1.4 \mathrm{~L} . \mathrm{h}^{-1}$, where the efficiency of the system was approximately $95 \%$.

Irrigation depths with levels of $25 \%, 50 \%, 75 \%$, $100 \%$ and $125 \%$ of the radish crop evapotranspiration were used. The values corresponding to the percentages of the irrigation depths are $28.55 \mathrm{~mm} ; 57.1 \mathrm{~mm} ; 85.65 \mathrm{~mm} ; 114.2$ $\mathrm{mm} ; 142.75 \mathrm{~mm}$ respectively.

In evaluating the productivity of the crop, the development of the variable fresh phytomass of the tuberous root (FPTR), an edible and commercialized part of the crop, was analyzed. All biometric variables were analyzed together in Boso et al. (2021).

\section{Fuzzy System}

From the data collected on the FPTR, fuzzy modeling was used. Two Fuzzy Rule-Based Systems (FRBS) were developed using membership functions, which can be represented graphically or numerically, with the assignment of fuzzy values to discrete values of variables in a numerical range. The membership functions reflect the intensity of each value in each linguistic term (David et al., 2016).

The first FRBS (Model 1) is composed of triangular membership functions for the input variable, and the second FRBS (Model 2) uses Gaussian membership functions, also for the input variable. Both systems are made up of triangular membership functions for the output variable. As an example, Figure 1a presents the configuration of the model based on the fuzzy rule base system, with a triangular membership function, for the input variable "irrigation depths". In the same way, the SBRF is represented, for Gaussian membership function, for the input variable (Figure 1b). 


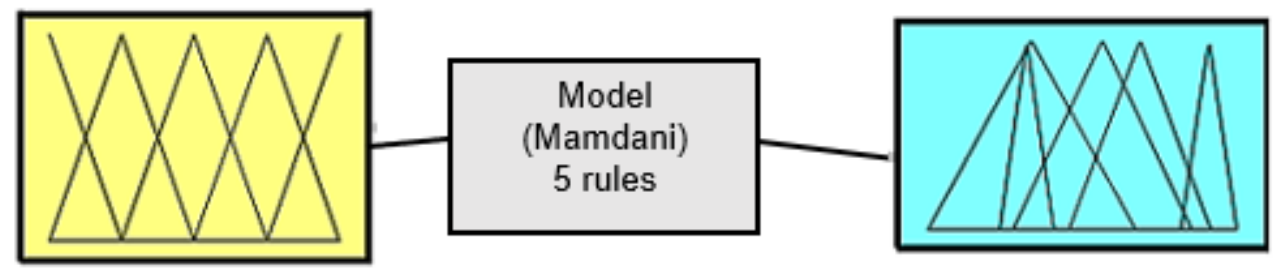

Irrigation depth (\% ETc)

Fresh phytomass of the tuberous root $(g)$

(a)

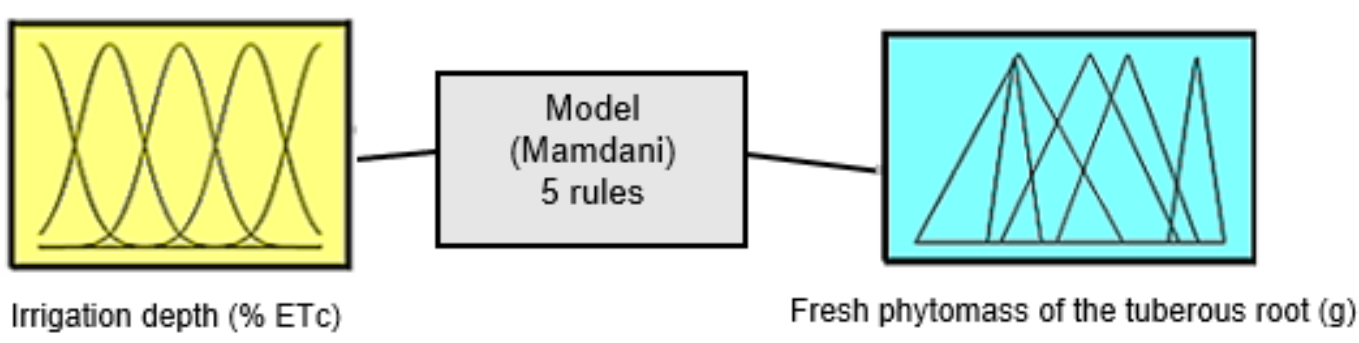

(b)

FIGURE 1. Fuzzy rule-based system for evaluating the radish crop (Model 1 and 2), with triangular and Gaussian membership functions, respectively, for the input variable (irrigation depth in $\%$ of ETc), 1 output variable (fresh phytomass of the tube rous root) and 5 rules.

The choice for the triangular membership function, in the input variable, occurred due to its advantages within the model. Its characteristics allow its points to coincide with the averages of the analyzed data, which provides better responses and performances on the coefficient of determination $\left(\mathrm{R}^{2}\right)$ and lesser model adjustment errors (Cremasco et al., 2010; Silva et al., 2014). However, the use of the triangular relevance function, in an agronomic way, is not acceptable.

Its presentation does not show smoothly the reality of the phenomenon that occurred, besides presenting great variations (peaks) in the results of the output variables, when there are changes in the initial data. For cases that require this smoothness, the use of the Gaussian membership function is more appropriate. This procedure was used similarly by Cremasco et al. (2010), Gabriel Filho et al. (2011, 2015, 2016), Pereira et al. (2008), Putti et al.
(2014, 2017a, 2017b, 2021), Viais Neto et al. (2019a, 2019b), Martínez et al. (2020), Matulovic et al. (2021) and Góes et al. (2021).

The systems are composed of an input variable (irrigation depth for crop evapotranspiration-\%), an output variable (biometric productivity variable - FPTR), and five rules for model execution. The input and output variables are composed of five delimiters.

The fuzzy models have the following characteristic: $F: X \subset \mathbb{R} \rightarrow \mathbb{R}$, such that $F=f(x)$, where $X$ is the domain set, composed of the variable "ETc irrigation depth (\%)", where $X=$ [25; 125]; and the codomain defined by the FPTR variable.

Table 1 shows the values of the delimiters of the triangular and Gaussian membership functions, for the irrigation depth input variable, of the developed fuzzy models.

TABLE 1. Delimiters of the filtered input variable for Model 1 with triangular membership functions, and Model 2 with Gaussian membership functions, where $C_{1}, C_{2}, C_{3}, C_{4}$ and $C_{5}$ are the fuzzy sets related as irrigation depths $25 \%, 50 \%, 75 \%, 100 \%$, and $125 \%$, respectively.

\begin{tabular}{|c|c|c|}
\hline Fuzzy Set & Model 1 & Delimiters \\
\hline$C_{1}$ & Triangular & {$\left[\begin{array}{lll}0 & 25 & 50\end{array}\right]$} \\
\hline$C_{2}$ & Triangular & {$\left[\begin{array}{lll}25 & 50 & 75\end{array}\right]$} \\
\hline$C_{3}$ & Triangular & {$\left[\begin{array}{lll}50 & 75 & 100\end{array}\right]$} \\
\hline$C_{4}$ & Triangular & {$\left[\begin{array}{lll}75 & 100 & 125\end{array}\right]$} \\
\hline$C_{5}$ & Triangular & {$\left[\begin{array}{lll}100 & 125 & 150\end{array}\right]$} \\
\hline Fuzzy Set & Model 2 & Delimiters \\
\hline$C_{1}$ & Gaussian & {$\left[\begin{array}{lllll}14,38 & 25 & 35,62\end{array}\right.$} \\
\hline$C_{2}$ & Gaussian & {$[39,385060,62]$} \\
\hline$C_{3}$ & Gaussian & {$[64,387585,62]$} \\
\hline$C_{4}$ & Gaussian & {$\left[\begin{array}{llll}89,38 & 100 & 110,62]\end{array}\right.$} \\
\hline$C_{5}$ & Gaussian & {$\left[\begin{array}{llll}114.38 & 125 & 135,62\end{array}\right]$} \\
\hline
\end{tabular}


Figure 2 represent the irrigation depths input variable in Models 1 and 2, with triangular and Gaussian membership functions, respectively.

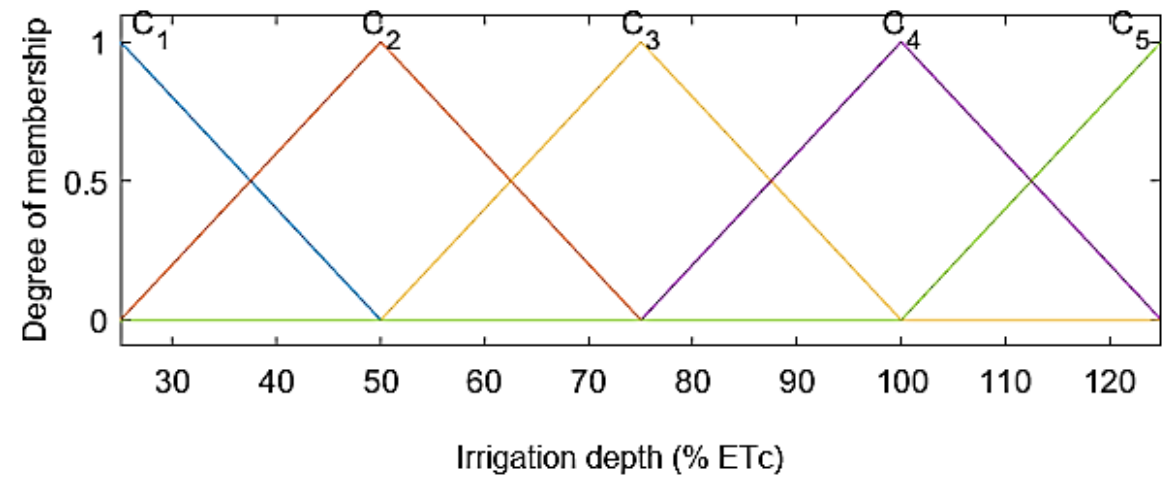

(a)

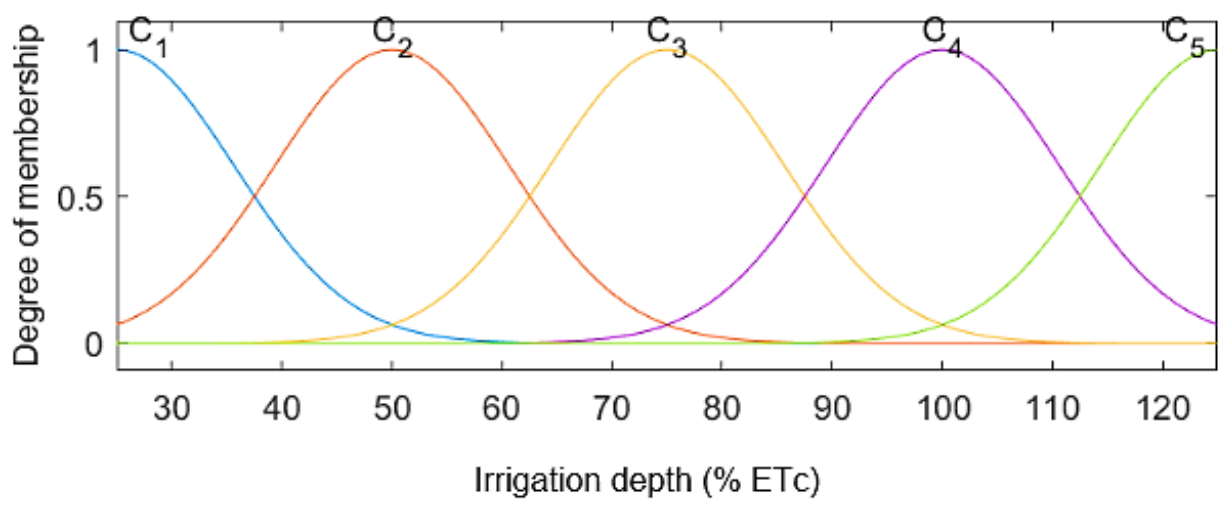

(b)

FIGURE 2. Triangular (a) and Gaussian membership functions and of the irrigation depth input variable in Model 1 and 2, respectively, related to the fuzzy sets $C_{1}, C_{2}, C_{3}, C_{4}$ and $C_{5}$, related to the irrigation depths $25 \%, 50 \%, 75 \%, 100 \%$, and $125 \%$, respectively, with points with pertinence degree varying between 0 and 1 .

For the computational components, the Microsoft Excel software, Fuzzy Logic Toolbox of the Matlab® software, and the Minitab software in version 17.0 (2014) were used.

\section{Models validation}

For the analysis and validation of fuzzy models efficiency, as well as for the a data comparison, we using a quadratic (second-order) polynomial model, with the objective of is to demonstrate a relationship between a dependent variable and one or more independent variables, using a mathematical model based on definitions (Toledo, 2015).

Since the fuzzy models here are generated as curve fitting models, you can quantify the yield of all models calculated with the coefficient of determination $\left(\mathrm{R}^{2}\right)$, the root mean square error (RMSE) and the mean absolute error (MAE). The coefficient of determination $\left(\mathrm{R}^{2}\right)$ consists of seeking to evaluate the quality of the model's adjustment in a range between 0 and 1, calculating the percentage or how much the model was able to explain the data collected experimentally (Ringle et al., 2014) The root mean square error (RMSE) and the mean absolute error (MAE), are measures of uncertainty in the model, where it indicates the size of the error caused by the model. The better the model fits, the smaller the error.

\section{RESULTS AND DISCUSSIONS}

From the analysis of the input data obtained in the study developed by Cremasco et al. (2015) and also from the development of this present work of fuzzy models for the productivity of the radish crop, the validation of the models with triangular and Gaussian membership functions were made with the input data and with the polynomial regression model (Table 2). Figure 3 shows the membership function of the output variable of the models developed to Models 1 and 2, respectively. 


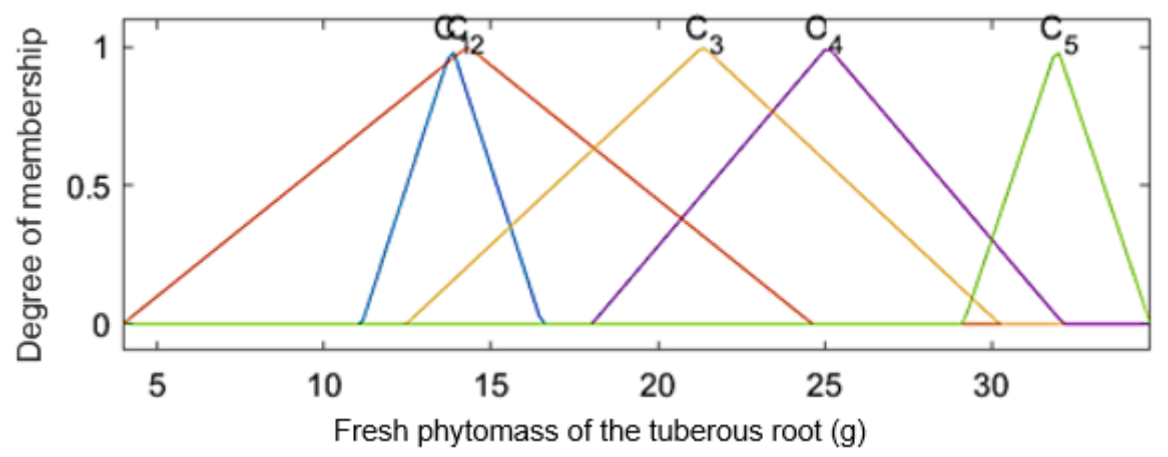

(a)

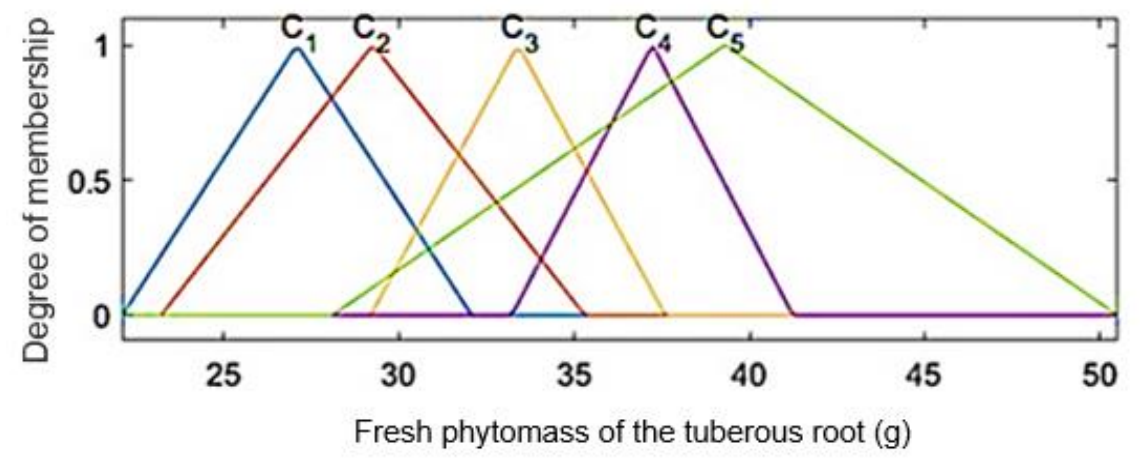

(b)

FIGURE 3. Triangular (a) and Gaussian (b) membership functions for the output variable fresh phytomass of the tuberous root for Models 1 and 2, respectively, where $C_{1}, C_{2}, C_{3}, C_{4}$ and $C_{5}$ are the fuzzy sets related to the irrigation depths $25 \%, 50 \%, 75 \%$, $100 \%$, and $125 \%$, respectively, with points with degree pertinence varying between 0 and 1.

TABLE 2. Results of the validation of fuzzy models of the productivity of the radish crop with triangular and Gaussian membership functions, and in the polynomial regression model, according to the coefficient of determination $\left(\mathrm{R}^{2}\right)$, the root mean square error (RMSE) and the mean absolute error (MAE).

\begin{tabular}{|c|c|c|c|}
\hline Index & $\begin{array}{c}\text { Model 1 } \\
\text { (Triangular) }\end{array}$ & $\begin{array}{c}\text { Model 2 } \\
\text { (Gaussian) }\end{array}$ & $\begin{array}{c}\text { Polynomial Regression: } \\
\mathrm{y}=\mathbf{- 0 . 0 0 3 . x ^ { 2 } + 0 . 4 3 9 . x + 7 . 7 7 2}\end{array}$ \\
\hline$R^{2}$ & $0,537(\mathrm{p}=0)$ & $0,504(\mathrm{p}=0.0001)$ & $0,104(\mathrm{p}=0.116)$ \\
\hline RMSE & 6.332 & 6.898 & 8.808 \\
\hline$M A E$ & 5.135 & 5.943 & 7.831 \\
\hline
\end{tabular}

It is observed that the model based on the polynomial regression did not present significant adjustment if compared with the coefficient of determination $\left(\mathrm{R}^{2}\right)$ of the fuzzy models. The two fuzzy models, with triangular and Gaussian membership functions, presented significant values about the polynomial regression model.

The fuzzy model with triangular function presented RMSE of 6.332 and MAE of 5.135, which indicates an adjustment of the model on the experimental data of the radish crop. The lower these values, the better the adjustment. With the same importance, the fuzzy model with the Gaussian membership function had to the RMSE of 6.898 and MAE of 5.43, showing an adequate adjustment on the analyzed data.

Studies proving the efficiency of fuzzy logic on polynomial regression analysis, in the interpretation of data, has been gaining great space in the academic environment. This can be seen in Viais Neto et al. (2018) in the evaluation of the production of cherry tomato seedlings, where the authors verified the superiority of the fuzzy logic in demonstrating which efficiently the growth of the crop with different levels of polymer doses and irrigation. Too in Putti et al. (2017b), verification of the effects generated to the wheat crop when submitted to fertilization of composted sewage residues.

The triangular fuzzy model showed good fit and smaller errors over the Gaussian fuzzy model (Figure 4). However, the triangular fuzzy model does not demonstrate with a smooth curve the reality of the agronomic phenomenon in productivity variable (FPTR). 


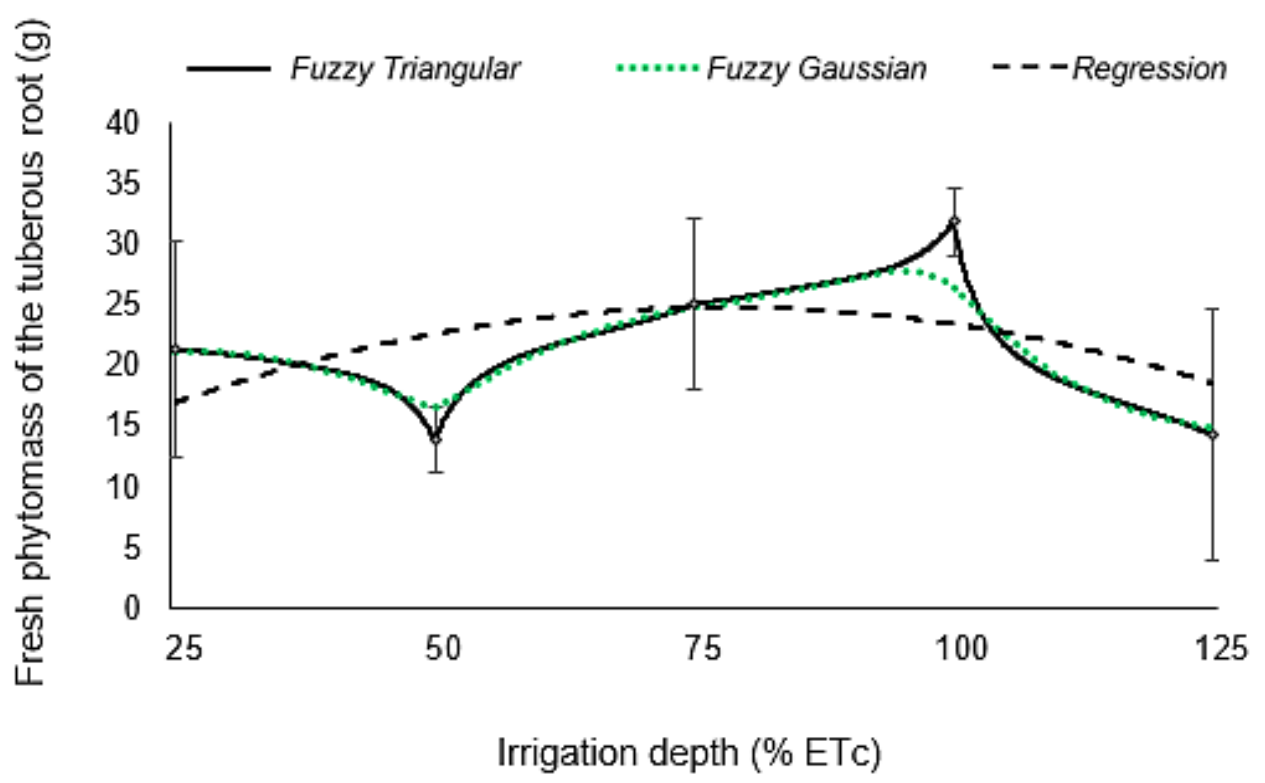

FIGURE 4. Comparison between the Models (triangular and Gaussian) of the productivity of radish crop.

Analyzing the response function, we verify the fuzzy model better estimated the productivity of the culture when compared with the regression model, where the depth of $100 \%$ of the ETc presented $31.9 \mathrm{~g}$. The regression model, on the other hand, showed productivity in the depth of $75 \%$, $(25.1 \mathrm{~g})$, which is lower than the average production acquired by the fuzzy model.

A similar result can be seen in the study developed by Silva et al. (2013), in the observation of the beet productivity in the $100 \%$ depth of ETc, when applied the fuzzy logic.

When analyzing the behavior of the crop development, we observed that the excess or lack of water, in the depths $50 \%$ and $125 \%$ of the ETc, caused the reduction of productivity, being inferior when observed by the fuzzy model. This reduction can be seen in the study developed by Bregonci et al. (2008) with the culture of radish. In his study, the author found that water stress applied at all stages of crop development caused a reduction in diameter and fresh phytomass of the tuberose root, promoting low productivity.

Agronomically comparing the performance of the fuzzy models developed, we saw that the fuzzy model with Gaussian membership functions presented curve with statistical significance $(p<0.05)$ in the description of the productivity of the radish crop. The smoothness of the curve describes homogeneously the effects on the productivity of the crop. This is due to the influence of the membership functions of the input variables in the fuzzy system.

Although the model with Gaussian membership function does not reach all midpoints, among the irrigation depths analyzed, its model tends to obtain little variation in the results when drastic changes are observed in the initial data, representing therefore a robust model.

However, this cannot be observed in model with the triangular membership functions, since any initial alteration can promote data peaks that do not demonstrate, in a real way, the study agronomic phenomenon. Thus, the use of the Gaussian membership function becomes more efficient in estimating the productivity of the radish crop.

\section{CONCLUSIONS}

The triangular fuzzy model estimated the best crop yield (31.9 $\mathrm{g}$ of fresh phytomass of the tuberous root) when using a $100 \%$ ETc depth. Also, the curve generated by this fuzzy model accurately represents all the averages of productivity-related each irritation depth.

Both models fuzzy (triangular and Gaussian) were validated and proved to be superior to quadratic polynomial regression, with higher $\mathrm{R}^{2}$ values and lower errors (RMSE and MAE). Also, it should be noted that, unlike the fuzzy models, the polynomial regression model presented an $\mathrm{R}^{2}$ value with $\mathrm{p}>0.05$, thus not representing therefore a significant model for the data. Thus, the importance of having a representative and significant model of data is emphasized, which was only possible with the use of fuzzy models.

Also, it should be noted that, although fuzzy modeling with triangular membership functions has shown better results in validating the model, fuzzy modeling with Gaussian relevance function proved to be more efficient in representing the agronomic reality due to the smooth behavior of the curve.

\section{ACKNOWLEDGMENTS}

This work was supported by the National Council for Scientific and Technological Development (CNPq) for the research productivity grants awarded to the penultimate and last authors (Process \#303923/2018-0 (FFP) and \#315228/2020-2 (LRAGF)).

\section{REFERENCES}

Bahuti M, Abreu LHP, Yanagi Junior T, Lima RR, Campos AT (2018) Performance of fuzzy inference systems to predict the surface temperature of broiler chickens. Engenharia Agrícola 38 (6):813-823. DOI: http://doi.org/10.1590/1809-4430-eng.agric.v38n6p813$823 / 2018$ 
Boso ACMR, Cremasco CP, Putti FF, Gabriel Filho LRA (2021) Fuzzy modeling of the effects of different irrigation depths on the radish crop. Part II: Biometric variables analysis. Engenharia Agrícola 41(3).

Bregonci IS, Almeida GD, Brum VJ, Zini Júnior A, Reis EF (2008) Desenvolvimento do sistema radicular do rabanete em condição de estresse hídrico. Idesia 26 (1):3338. DOI: http://doi.org/10.4067/S0718-

34292008000100005

Coutinho Neto AM, Orioli Júnior V, Cardoso SS, Coutinho ELM (2010) Produção de matéria seca e estado nutricional do rabanete em função da adubação nitrogenada e potássica. Nucleus 7 (2):105-114. DOI: http://doi.org/10.3738/nucleus.v7i2.349

Cremasco CP, Gabriel Filho LRA, Cataneo A (2010) Metodologia de determinação de funções de pertinência de controladores fuzzy para a avaliação energética de empresas de avicultura de postura. Revista Energia na Agricultura 25 (1):21-39. DOI:

http://doi.org/10.17224/EnergAgric.2010v25n1p21-39

Cremasco CP. Gabriel Filho LRA, Putti FF, Ludwig R, Silva Júnior JF (2015) Resposta da cultura do rabanete irrigado com água tratada magneticamente e convencional. In: Congresso Brasileiro de Engenharia Agrícola. São Pedro, Associação Brasileira de Engenharia Agrícola, Proceedings...

David GS, Rizol PMSR, Nascimento LFC (2016) Modelos computacionais fuzzy para avaliar efeitos da poluição do ar em crianças. Revista Paulista de Pediatria 36(1):10-16. DOI: http://doi.org/10.1590/1984-0462/;2018;36;1;00013

Dutra M, Deboni TC, Volpi PSB, Matias JFG, Nesi BZ (2014) Avaliação produtiva de rabanete Raphanus Sativus L. submetido a preparados homeopáticos de tiririca Cyperus rotundus. Revista Brasileira de Agroecologia 9 (2):151-159.

Gabriel Filho LRA, Pigatto GAS, Lourenzani AEBS (2015) Fuzzy rule-based system for evaluation of uncertainty in cassava chain. Engenharia Agrícola 35(2):350-367. DOI: http://doi.org/10.1590/1809-4430-

Eng.Agric.v35n2p350-367/2015

Gabriel Filho LRA, Putti FF, Cremasco CP, Bordin D, Chacur MGM, Gabriel LRA (2016) Software to assess beef cattle body mass through the fuzzy body mass index. Engenharia Agrícola 36(1):179-193. DOI:

http://doi.org/10.1590/1809-4430-Eng.Agric.v36n1p179$193 / 2016$

Gabriel Filho RA, Cremasco CP, Putti FF, Chacur MGM (2011) Application of fuzzy logic for the evaluation of livestock slaughtering. Engenharia Agrícola 31(4):813825. DOI: http://doi.org/10.1590/S010069162011000400019

Góes BC, Goes RJ, Cremasco CP, Gabriel Filho LRA (2021) Fuzzy modeling of vegetable straw cover crop productivity at different nitrogen doses. Modeling Earth Systems and Environment: 7. DOI: http://doi.org/10.1007/s40808-021-01125-4.
Kisi O (2013) Applicability of Mamdani and Sugeno fuzzy genetic approaches for modeling reference evapotranspiration. Journal of hydrology 504:160-170. DOI: http://doi.org/10.1016/j.jhydrol.2013.09.043

Martínez MP, Cremasco CP, Gabriel Filho LRA, Braga Junior SS, Bednaski AV, Quevedo-Silva F, Correa CM, Silva D, Padgett RCML (2020) Fuzzy inference system to study the behavior of the green consumer facing the perception of greenwashing. Journal of Cleaner Production 242(1):116064. DOI:

http://doi.org/10.1016/j.jclepro.2019.03.060

Matos RM, Silva PF, Lima SC, Cabral AA, Dantas Neto J (2015) Partição de assimilados em plantas de rabanete em função da qualidade da água de irrigação. Journal of Agronomic Sciences 4(1):151-164.

Matulovic M, Putti FF, Cremasco CP, Gabriel Filho LRA (2021) Technology 4.0 with 0.0 costs: fuzzy model of lettuce productivity with magnetized water. Acta Scientiarum Agronomy: 43. DOI: http://doi.org/10.4025/actasciagron.v43i1.51384

Pereira DF, Bighi CA, Gabriel Filho LRA, Cremasco CPC (2008) Sistema fuzzy para estimativa do bem-estar de matrizes pesadas. Engenharia Agrícola 28(4):624-633. DOI: http://doi.org/10.1590/S0100-69162008000400002

Putti FF, Gabriel Filho LRA, Gabriel CPC, Bonini Neto A, Bonini CSB, Reis AR (2017) A Fuzzy mathematical model to estimate the effects of global warming on the vitality of Laelia purpurata orchids. Mathematical Biosciences 288(6):124-129. DOI: http://doi.org/10.1016/j.mbs.2017.03.005

Putti FF, Gabriel Filho LRA, Silva AO, Ludwig R, Gabriel CPC (2014) Fuzzy logic to evaluate vitality of catasetum fimbiratum species (Orchidacea). Revista Irriga 19(3):405413. DOI: http://doi.org/10.15809/irriga.2014v19n3p405

Putti FF, Kummer ACB, Grassi Filho H, Gabriel Filho LRA, Cremasco CP (2017) Fuzzy modeling on wheat productivity under different doses of sludge and sewage effluent. Engenharia Agrícola 37(6):1103-1115. DOI: http://doi.org/10.1590/1809-4430-eng.agric.v37n6p1103$1115 / 2017$

Putti FF, Lanza MH, Grassi Filho H, Cremasco CP, Souza AV, Gabriel Filho LRA (2021) Fuzzy modeling in orange production under different doses of sewage sludge and wastewater. Engenharia Agrícola, 41(2):204-214. DOI: http://doi.org/10.1590/1809-4430-eng.agric.v41n2p204$214 / 2021$

Raj R, Mohan BM (2016) Modelling and analysis of the simplest fuzzy PI/PD controllers of Takagi-Sugeno type. IFAC-PapersOnLine 49(1):537-542. DOI: http://doi.org/10.1016/j.ifacol.2016.03.110

Ringle CM, Silva D, Bido D (2014) Modelagem de equações estruturais com utilização do smartpls. Revista Brasileira de Marketing 13(2):56-73. 
Rodrigues RR, Pizetta SC, Teixeira AG, Reis EF, Hott MO (2013) Produção de rabanete em diferentes disponibilidades de água no solo. Enciclopédia Biosfera 9(17):2121-2130. DOI:

Salgado CM, Vieira SM, Mendonça LF, Finkelstein S, Sousa JMC (2016) Ensemble fuzzy models in personalized medicine: Application to vasopressors administration. Engineering Applications of Artificial Intelligence 49:141148. DOI: http://doi.org/10.1016/j.engappai.2015.10.004

Santos JCC, Silva CH, Santos CS, Silva CS, Melo EB, Barros AC (2014) Análise de crescimento e evapotranspiração da cultura do rabanete submetido a diferentes lâminas de água. Revista Verde 9(1):151-156.

Senna P, Tanscheit R, Gomes AM (2015) Planejando o processo de previsão de demanda com auxílio da lógica fuzzy. Revista Produção e Desenvolvimento 1 (2) p: 90-103.

Silva AAV, Silva IAF, Teixeira Filho MCM, Buzetti S, Teixeira MCM (2014) Estimativa da produtividade de trigo em função da adubação nitrogenada utilizando modelagem neuro fuzzy. Revista Brasileira de Engenharia Agrícola e Ambiental 18(2):180-187. DOI: http://doi.org/10.1590/S1415-43662014000200008

Silva AFA, Souza EGF, Santos MG, Barros Júnior AP, Bezerra Júnior F, Silveira LM (2015) Rentabilidade do rabanete adubado com flor-de-seda em duas épocas de cultivo no semiárido de Pernambuco. Revista de Ciências Agrárias 58(2):198-207. DOI: http://doi.org/10.4322/rca.1761

Silva BEM, Cláudio AA, Rêgo VM, Silvério AT (2015) Características produtiva do rabanete submetido a doses de cinza vegetal. Enciclopédia Biosfera 11(21):241-432.
Silva JM, Ferreira RS, Melo AS, Suassuna JF, Dutra AF, Gomes JP (2013) Cultivo do tomateiro em ambiente protegido sob diferentes taxas de reposição da evapotranspiração. Revista Brasileira de Engenharia Agrícola e Ambiental 17(1):40-46. DOI: http://doi.org/10.1590/S1415-43662013000100006

Sousa CA, Duarte PS, Pereira JCR (2006) Lógica fuzzy e regressão logística na decisão para prática de cintilografia das paratiróides. Revista Saúde Pública 40(5):898-906. DOI: http://doi.org/10.1590/S0034-89102006000600021.

Toledo GL (2015) Estatística básica. São Paulo, Atlas, p. 412-457.

Viais Neto DS, Cremasco CP, Bordin D, Putti FF, Silva Junior JF, Gabriel Filho LRA (2019) Fuzzy modeling of the effects of irrigation and water salinity in harvest point of tomato crop. Part I: description of the method. Engenharia Agrícola 39(3):294-304. DOI: http://doi.org/10.1590/18094430-eng.agric.v39n3p294-304/2019

Viais Neto DS, Cremasco CP, Bordin D, Putti FF, Silva Junior JF, Gabriel Filho LRA (2019) Fuzzy modeling of the effects of irrigation and water salinity in harvest point of tomato crop. Part II: Application and interpretation. Engenharia Agrícola 39(3):305-14. DOI:

http://doi.org/10.1590/1809-4430-eng.agric.v39n3p305$314 / 2019$

Viais Neto DS, Pradela VA, Gabriel Filho LRA, Cremasco CP, Maria ACG, Oliveira GS (2018) Modelagem fuzzy para avaliação da produção de mudas de tomate cereja utilizando diferentes doses de polímeros e níveis de irrigação. Colloquium Agrariae 14(3):93-103. DOI: http://doi.org/10.5747/ca.2018.v14.n3.a231 